I NTERNATIONALMONETARY FUND

Monetary and Capital Markets Department

\title{
Shadow Banking and Market-Based Finance
}

Tobias Adrian and Bradley Jones

No. $18 / 14$ 
Monetary and Capital Markets

\section{Shadow Banking and Market-Based Finance}

Tobias Adrian and Bradley Jones

$\begin{array}{llllllllllllllllllllllll}\text { I N T E R N A T I O N A L M O N } & \text { N } & \text { E T A R } & \text { Y } & \text { F U N } & \text { D }\end{array}$ 
Copyright @2018 International Monetary Fund

\title{
Cataloging-in-Publication Data
}

\author{
Joint Bank-Fund Library
}

Names: Adrian, Tobias, 1971- | Jones, Bradley Anthony. | International Monetary Fund. | International Monetary Fund. Monetary and Capital Markets Department.

Title: Shadow banking and market-based finance / Tobias Adrian and Bradley Jones.

Other titles: Departmental paper series (International Monetary Fund. Monetary and Capital Markets

Department)

Description: Washington, DC : International Monetary Fund, 2018. | At head of title: Monetary and Capital

Markets Department. | Includes bibliographical references.

Identifiers: ISBN 978-1-48434-388-3 (paper)

Subjects: LCSH: Intermediation (Finance) | Nonbank financial institutions. | Credit. | Stock exchanges—Law and legislation.

Classification: LCC HG3891.5 .A334 2018

The Departmental Paper Series presents research by IMF staff on issues of broad regional or cross-country interest. The views expressed in this paper are those of the author(s) and do not necessarily represent the views of the IMF, its Executive Board, or IMF management.

Publication orders may be placed online, by fax, or through the mail:

International Monetary Fund, Publication Services

P.O. Box 92780, Washington, DC 20090, U.S.A.

Tel. (202) 623-7430 Fax: (202) 623-7201

E-mail: publications@imf.org

www.imfbookstore.org

www.elibrary.imf.org 


\section{Contents}

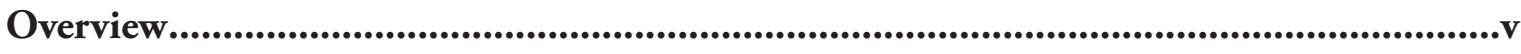

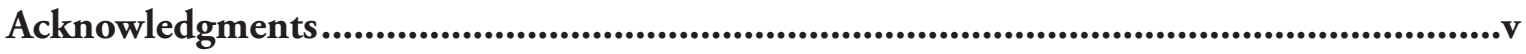

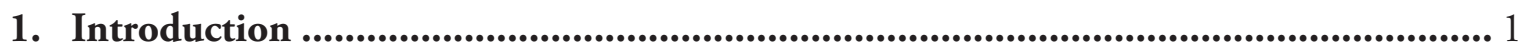

2. Nonbank Credit Intermediation-A Conceptual Framework...................................... 3

3. The Postcrisis Evolution...................................................................................... 11

4. Strengthening Supervision and Regulation.............................................................. 15

5. Case Studies of Policy Challenges on the Horizon ................................................... 23

Conclusion ................................................................................................................. 33

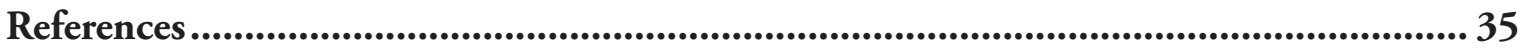

\section{Figures}

3.1. Global Nonbank Credit Intermediation, by FSB Economic Function....................12

3.2. US Nonbank Credit Intermediation, by Vehicle Type ...................................... 13

3.3. Share of Worldwide Money Market Fund Assets ............................................... 13

4.1. US Money Market Fund Assets ................................................................. 17

4.2. "Riskier" US Residential Mortgage-Backed Securities......................................... 18

4.3. US Mortgage-Backed Securities: Agency versus Nonagency ...............................20

5.1. Nonbank Credit Intermediation in China.......................................................24

5.2. Depository Institution Bank Claims on Other Financial Institutions in China......25

5.3. US Leveraged Loans: Outstanding Volume and Spreads....................................27

5.4. US Leveraged Loans: Issuance of Lowly Rated Debt (B-Rated or Lower) ..............28

5.5. US Leveraged Loans: Issuance of Lowly Rated Debt (B-Rated or Lower) ..............29

5.6. Subprime Auto-Loan Asset-Backed Securities ...................................................... 30

Table

2.1. A Stylized View of the Structural Characteristics of Credit Intermediation ..............4 



\section{Overview}

Variants of nonbank credit intermediation differ greatly. We provide a conceptual framework to help distinguish various characteristics — structural features, economic motivations, and risk implications — associated with different forms of nonbank credit intermediation. Anchored by this framework, we take stock of the evolution of shadow banking and the extent of its transformation into market-based finance since the global financial crisis. In light of the substantial regulatory and supervisory responses of recent years, we highlight key areas of progress while drawing attention to elements where work still needs to be done. Case studies of policy challenges arising in different jurisdictions are also discussed. While many of the amplification forces that were at play during the global financial crisis have diminished, the postcrisis reform agenda is not yet complete, and policymakers must remain attentive to new challenges looming on the horizon.

\section{Acknowledgments}

This paper builds on a speech at the 33rd SUERF colloquium held at the Bank of Finland in Helsinki, Finland, on September 14, 2017. The authors would like to thank Peter Breuer, Chris Colford, Pete Dattels, Daniel Hardy, Dong He, Nigel Jenkinson, Hui Miao, Aditya Narain, Fabio Natalucci, Robert Patalano, Christoph Rosenberg, Ratna Sahay, Manmohan Singh, Narayan Suryakumar, and other colleagues in the Money and Capital Markets Department for helpful comments. 



\section{Chapter}

\section{1 intoduction}

Innovations in nonbank credit intermediation (NBCI) represent, just like any form of financial intermediation, a response to the unmet needs and preferences of borrowers and lenders. By helping to complete markets-for instance, by giving issuers new outlets for capital raising when bank lending is unavailable, and providing lenders more avenues for portfolio diversification-NBCI might yield greater efficiencies and risk-sharing capacity.

However, the global financial crisis and ensuing aftershocks have also brought into sharp focus the risks to financial stability associated with NBCI. Until recently, the label "shadow banking" has been broadly used to characterize private credit intermediation occurring outside the formal banking system. ${ }^{1}$ Yet general labels can be of limited usefulness if they obscure attention from the widely varying structural characteristics and economic motivations of NBCI - particularly where disentangling these features might help inform more nuanced assessments of the risks, if any, that different forms of NBCI pose to financial stability. In short, not all forms of NBCI are created equal.

This paper begins by laying out a conceptual framework for distinguishing features of shadow banking that make it a less resilient form of market-based finance. In doing so, we build on earlier IMF analysis and that of the Financial Stability Board (FSB) (see, for instance, IMF 2014, 2015; FSB 2015, 2017b), which in response to a request from the Group of 20 (G20) leaders at the 2010 Seoul Summit has been instrumental in driving the international effort to make NBCI more resilient. This framework then grounds the discussion of the following issues: How have the different forms of shadow banking — and market-based finance more generally—that make up NBCI evolved

\footnotetext{
1The term "shadow banking" was coined by McCulley (2007), with taxonomies provided shortly thereafter by Pozsar (2008) and Adrian and Shin (2009, 2011). A voluminous related literature has since emerged. For recent reviews, see IMF (2014) and Claessens and others (2015).
} 
in the wake of the global financial crisis? Given the concerted regulatory and supervisory response since the crisis, where has most progress been made and where is there still work to be done? And, from a regional financial stability perspective, what are some of the more pressing policy challenges posed by emerging trends in shadow banking and market-based finance? 


\section{ChAPTER}

\section{Nonbank Credit Intermediation-A}

Policy analysis of NBCI has recently begun to describe shadow banking as a less resilient form of market-based finance (FSB 2015, 2017b). However, as a relatively greenfield area, related discussion has left open the question of what it is about the particular features of shadow banking that might make it less resilient. Against this background, we outline a simple, stylized framework to help identify particular aspects of shadow banking along three main dimensions: structural characteristics, economic motivations, and financial stability implications.

\section{Structural Characteristics}

Credit intermediation can take a variety of functional forms. As such, identifying the structural characteristics of credit intermediation-shadow banking and more resilient forms of market-based finance, as well as traditional banking-offers a useful point of departure for a discussion of possible financial stability implications (Table 2.1 ): ${ }^{1}$

- Transformations of Risk Characteristics_-Shadow banking activities can involve extensive transformation of risk characteristics. Key in this regard is credit enhancement associated with the pooling and tranching of risk, and/ or implicit guarantees. While maturity and/or liquidity transformation is typically associated with all types of credit intermediation (shadow banking, market-based finance, and traditional banking), leverage, complexity, and opaqueness tend to be more prominent in the case of shadow banking than in other forms of credit intermediation. The archetype example pertains to the transformation of a portfolio of illiquid, subprime loans on bank balance sheets (with the help of a sophisticated pricing model) into

${ }^{1}$ This synthesis is derived in part from that presented in Adrian (2015). 
Table 2.1. A Stylized View of the Structural Characteristics of Credit Intermediation

\begin{tabular}{|c|c|c|c|}
\hline Characteristic & $\begin{array}{l}\text { Traditional } \\
\text { Banking }\end{array}$ & $\begin{array}{l}\text { Riskier Elements of } \\
\text { Shadow Banking Activity }\end{array}$ & $\begin{array}{l}\text { Resilient Elements of } \\
\text { Market-Based Finance }\end{array}$ \\
\hline Examples & Commercial bank & $\begin{array}{l}\text { Synthetic CDO, Structured } \\
\text { Investment Vehicle, CNAV } \\
\text { MMF, ABCP Conduit }\end{array}$ & $\begin{array}{l}\text { Direct lending by pension } \\
\text { or SWF fund, distressed } \\
\text { debt or PE partnerships }\end{array}$ \\
\hline $\begin{array}{l}\text { Key Risk } \\
\text { Transformations }\end{array}$ & $\begin{array}{l}\text { Liquidity, maturity, } \\
\text { leverage }\end{array}$ & $\begin{array}{l}\text { Credit enhancement, } \\
\text { liquidity, maturity, leverage }\end{array}$ & $\begin{array}{l}\text { Less emphasis on credit } \\
\text { enhancement and less } \\
\text { opaque vs. shadow } \\
\text { banking }\end{array}$ \\
\hline $\begin{array}{l}\text { Institutions Involved } \\
\text { in Intermediation }\end{array}$ & Single entity & $\begin{array}{l}\text { Can be many entities, } \\
\text { interconnected through } \\
\text { collateral chains and credit } \\
\text { guarantees }\end{array}$ & Single/few entities \\
\hline $\begin{array}{l}\text { Formal Official } \\
\text { Backstop }\end{array}$ & Yes & $\begin{array}{l}\text { No, but possibly indirect } \\
\text { access }\end{array}$ & No \\
\hline $\begin{array}{l}\text { Implied Private } \\
\text { Sponsor Support }\end{array}$ & n.a. & $\begin{array}{l}\text { Yes, can sometimes be } \\
\text { contingent liabilities }\end{array}$ & $\begin{array}{l}\text { No, insolvency remote } \\
\text { for sponsor }\end{array}$ \\
\hline $\begin{array}{l}\text { Key Features of } \\
\text { Funding Base }\end{array}$ & $\begin{array}{l}\text { Mix of debt and } \\
\text { deposits, wholesale } \\
\text { and retail-financed }\end{array}$ & Highly runnable & Less runnable \\
\hline
\end{tabular}

Source: IMF.

Note: $\mathrm{CDO}=$ collateralized debt obligation $; \mathrm{CNAV}=$ constant net asset value; $\mathrm{MMF}=$ money market fund; $\mathrm{ABCP}=$ asset-backed commercial paper; $\mathrm{SWF}=$ sovereign wealth fund, $\mathrm{PE}=$ private equity.

an off-balance-sheet portfolio of liquid, highly rated securities, some of which enjoy credit support features (provided by the sponsor) not present in the underlying loans. By contrast, the relative resilience of market-based finance is reflected in less pronounced risk transformation and possibly reduced complexity and opaqueness.

- Lengthy Networks - The risk transformations inherent to shadow banking are often performed along a chain of specialized and interconnected intermediaries, and can thereby involve the balance sheets of many entities. ${ }^{2}$ For instance, loans originated by a nonbank finance company are pooled and warehoused by broker-dealers, whose syndicate desks structure them into asset-backed and collateralized debt obligation (CDO) securities, which are assigned ratings by credit rating agencies (CRAs), and funded through the issuance of capital notes on the wholesale market, to be purchased by enhanced cash funds. A related feature of shadow banking is the reuse of collateral and lengthy collateral chains. While collateralized borrowing is generally safe, one drawback is that frequently reused collateral can give rise to heightened interconnectedness. ${ }^{3}$ Meanwhile, market-based finance can

\footnotetext{
${ }^{2}$ For a general discussion, see Pozsar and others (2013). For a similar discussion as it pertains specifically to the intermediation chain in securitization markets, see Segoviano and others (2015).

${ }^{3}$ See, for instance, Singh $(2011,2013,2017)$. As Muley (2016) also points out, collateral intermediation chains can take two general forms-where the value of pledgeable collateral, and hence the amount that can
} 
be associated with reduced scope for spillovers where interconnectedness across financial institutions is much reduced. Take, for instance, the case of a direct loan to a firm extended by a long-term asset owner (for example, an endowment or sovereign wealth fund): the credit risk is borne by the single institution (ring-fenced), without giving rise to potential contagion effects as can arise in the presence of lengthy rehypothecation chains.

- Implicit Private Sponsor Support_-Shadow banking activity often benefits from the presumption of private sponsor support, such as an implied credit guarantee or a credit line to an off-balance-sheet entity provided by a bank concerned with incurring reputational damage if investor return expectations are not met. Where shadow banking activities have margins that are so low that they cannot absorb the full cost of a backstop by themselves, they require subsidized external risk absorption capacity (that is, cheap insurance). The more resilient aspect of market-based finance finds expression in a self-supporting financing structure, in the sense that the underlying business model does not rely on the presumption of sponsor support in bad states of the world to reduce the cost of funding.

- Formal versus Indirect Access to Official Backstops-While neither shadow banking nor market-based finance entities have formal access to official-sector backstops (that is, discount window access and deposit insurance) in the manner of a traditional deposit-taking bank, shadow banks might benefit from indirect (backdoor) access due to their closer linkages with traditional banks (see below).

- Funding Base-The dominant feature of shadow banking liabilities is that they are principally short-term runnable instruments, while the more resilient funding base of market-based activity is reflected in longer-term and less runnable forms of financing.

Some caveats are important, however. First, Table 2.1 serves only as a stylized framework, where distinctions for shadow banking, as a less resilient form of market-based finance, are made to appear sharper than is often the case in practice. There can be many shades of gray depending on which structural feature of NBCI is under discussion (as particularly with bond mutual funds, where risk transformations pertain mainly to liquidity). Second, and related, while shadow banking is a less resilient form of market-based finance in general, this distinction does not speak to credit risk per se. Third, despite this lower level of resilience, there can still be an important place for shadow banking in the wider credit intermediation ecosystem, for instance by helping to complete markets and intermediate flows between willing borrowers and lenders with a range of objectives and risk tolerances.

be borrowed, is limited by the face value of the original debt contract (that is, securitization) and where the collateral enables the borrowing of an amount greater than the face value of the debt backed by that collateral (that is, rehypothecation). 


\section{Economic Motivations for Intermediaries}

Structural characteristics are not the only means by which to distinguish different forms of (nonbank) credit intermediation. Understanding the underlying motivations for agents to intermediate credit in the form they do might also yield insights relevant for financial stability. ${ }^{4}$

- Agency Frictions and Informational Asymmetries-While agency problems are omnipresent in finance in general, ${ }^{5}$ including in market-based finance, misaligned incentive problems can be magnified in certain shadow banking contexts in the presence of a high degree of complexity, specialization, and opaqueness. These features afford agents scope to exploit informational asymmetries in a manner capable of generating negative externalities. ${ }^{6}$ The predatory lending practices of originators, or the adverse-selection problems that allow securitization arrangers to retain high-quality loans while securitizing the "lemons," were prominent shadow banking examples brought to light by the global financial crisis. ${ }^{7}$ Additionally, while the issuer-pays business model for credit ratings can lead to ratings inflation in many contexts, including market-based finance, the crisis illustrated that it was especially pronounced in shadow banking activities. Heightened complexity often results in investors outsourcing aspects of their due diligence process by relying heavily on external credit rating assessments. And because issuers have the ability to "ratings shop" - it is they, rather than the investor, who employ the services of the rating agency-agencies have a strong incentive to assign ratings in a manner that maximizes the probability of winning business from issuers, which is particularly lucrative in structured products.

\footnotetext{
${ }^{4} \mathrm{It}$ is beyond the scope of this paper to offer a treatment of the potential impact of a full range of macroeconomic determinants of NBCI activity (that is, changes in monetary policy or national savings patterns).

${ }^{5}$ This is in part because of asymmetric compensation structures that allow agents to effectively restrike a call option each year (in the absence of clawbacks) in which they have unlimited upside with limited downside. Convex payoff structures of this kind can generate a rational preference for aggressive forms of risk taking that are not necessarily in the best interests of principals or the broader financial system. See for instance, Allen and Gorton (1993), Allen and Gale (2000), Rajan (2005), Stein (2013a), and Jurek and Stafford (2015).

${ }^{6}$ Ashcraft and Schuermann (2008) identified no fewer than seven informational frictions in the securitization of subprime mortgages prior to the financial crisis.

${ }^{7}$ Another example of asymmetric information brought to light by the crisis was the CDO structuring activity of investment banks, which, with access to granular loan-level data on borrower repayment capacity, iterated default correlation assumptions in such a way as to maximize the size of a tranche of greatest appeal to target investors. Because investment mandate restrictions and provisioning charges meant that institutional investors were often confined or strongly encouraged to buy highly rated securities, there were strong incentives for issuers to structure securities on the basis of benign correlation assumptions - that is, those that tend to prevail most of the time, rather than during periods of heightened systemic risk. (This connects to the literature on "neglected risk"; see, for instance, Coval, Jurek, and Stafford (2009) and Gennaioli, Shleifer, and Vishny (2012).) This left investors with an economic exposure functionally equivalent to being short catastrophe insurance.
} 
This behavior has been recognized to have played an important role in amplifying the effects of the crisis. ${ }^{8}$

- (Mispriced) Sponsor Backstops and Contingent Liabilities-Because commercial banks benefit from direct access to official-sector backstops, their credit support lines to shadow banking affiliates can reduce the cost of the latter's liabilities and leave investors with the presumption that these liabilities are ostensibly "money good." Both features act to stimulate investment demand. In its purest form, resilient market-based finance has no need to exploit sponsor backstops or give rise to contingent liabilities.

- Regulatory Arbitrage — Shadow banking activities can also be motivated by the circumvention of capital, liquidity, taxation, or information requirements to make activities profitable that might otherwise not be. A notable example prior to the crisis was seen in the provision of bank guarantees to asset-backed commercial paper (ABCP) conduits in the United States that were structured as liquidity-enhancing guarantees rather than credit guarantees. In some circumstances, this had the effect of reducing regulatory capital charges nine-fold. ${ }^{9}$

\section{Financial Stability Implications}

A third — and the most consequential — dimension along which market-based finance and less resilient forms of shadow banking can be distinguished relates to the degree to which such activities contribute more to variability in

\footnotetext{
${ }^{8}$ Empirical studies, including Griffin and Tang (2012) and He, Qian, and Strahan (2012), have documented inflated credit ratings assigned to mortgage-backed securities before the crisis. Jiang, Stanford, and Xie (2012) show that rating agencies assign higher credit ratings after switching from the "investor-pays" to the "issuer-pays" business model. Strobl and Xia (2012), Cornaggia and Cornaggia (2013), and Segoviano and others (2015) discuss the conflicts of interest leading to credit rating inflation. More generally, the United States Financial Crisis Inquiry Report concluded that "the failures of credit rating agencies were essential cogs in the wheel of financial destruction."

${ }^{9}$ Under the Basel I and II frameworks, little capital (or zero in the case of Basel I) was required for credit exposures to, or liquidity support for, banks' off-balance-sheet ABCP and other securitization vehicles, compared to holding the underlying assets on their balance sheet. One result was that while the Financial Accounting Standards Board issued guidance in 2003 to the effect that sponsoring banks should consolidate assets in ABCP conduits onto their balance sheets, US banking regulators clarified that these assets would not, in fact, need to be included in the measurement of risk-based capital. Instead, a 10 percent credit conversion factor for the amount covered by a liquidity guarantee was imposed, which in effect meant that regulatory charges for conduit assets covered by liquidity guarantees were 90 percent lower than regulatory charges for on-balance-sheet financing. In response, the majority of guarantees were structured as liquidity-enhancing guarantees, aimed at minimizing regulatory capital, instead of credit guarantees. Unsurprisingly, the majority of conduits were supported by commercial banks subject to the most stringent capital requirements. See Acharya, Schnabl, and Suarez (2013).
} 
the market price of risk, or systemic risk. ${ }^{10}$ Controlling for size, there are firm grounds to suggest that shadow banking is more amenable to giving rise to systemic risk, owing not only to the earlier-discussed structural characteristics and economic motivations, but also to the (in)adequacy of policy instruments available to dampen associated vulnerabilities.

Changes in the market price of risk (that is, risk premiums) could be a rational response to a change in fundamentals, or they could reflect frictions in market-based finance like the synchronized herding of investors who respond procyclically to past performance. In either case, real economic consequences could result, reflected in, for example, higher corporate borrowing costs or negative wealth effects. Indeed, the first-mover advantage and synchronized herding effects in fund management have been shown to amplify movements in market prices. ${ }^{11}$ But while shifts in the price of risk induced by market-based financial frictions can be an ingredient in systemic risk, other amplification mechanisms, like leverage and institutional interconnectedness, can be needed to generate systemic implications. ${ }^{12}$ Viewed differently, a rich literature has emerged to show that, while limits-to-arbitrage can prevent dislocations in market trading conditions from swiftly self-correcting, this tends to connect more to issues of market efficiency than systemic risk per se. ${ }^{13}$ More generally, it remains hotly contested whether policymakers should even try to influence the market price of risk, and, even if so, how best, and under what conditions, to do it. ${ }^{14}$

By contrast, the desire of policymakers to defend against systemic risk is universal. Of concern in this regard is that while not all shadow banking is

\footnotetext{
${ }^{10}$ As it will not be unusual for modes of NBCI to share at least some features of both shadow banking and market-based finance as earlier described, determining whether these activities pose systemic risk could serve as the primary consideration in their categorization. This aligns with the FSB's approach in referring to market-based finance as the more resilient form of credit intermediation.

${ }^{11}$ IMF (2015). Note this work did not aim to provide a verdict on the overall systemic importance of asset management activities and firms. However, it did reveal that unlike banks, larger funds and funds managed by larger asset management companies do not necessarily contribute disproportionately more to systemic risk.

${ }^{12}$ Leverage can both accelerate the process of fire sales and reduce the ability of institutions to absorb losses. The Long-Term Capital Management episode in 1998 is a clear example in funds management where high levels of leverage and institutional interconnectedness combined to result in large changes in risk premiums mutating into systemic risk.

${ }^{13}$ Note that in October 1987, when the US equity market shed about one-quarter of its value in a single day, no financial institution of any significance failed, and real GDP in that quarter went on to expand at an annualized rate of more than 6 percent. Nevertheless, given the rising share of institutional investment activity and the more widespread use of leverage over recent decades, it is not clear that a repeat episode would end so benignly.

${ }^{14} \mathrm{An}$ extensive literature has emerged on the conditions under which authorities should consider leaning against time-varying risk premiums. For recent US-centric reviews, see Stein (2013b) and Mishkin (2010, 2011). Jones (2015) provides a contemporary synthesis of the competing "Jackson Hole" and "Basel Consensus" paradigms.
} 
potentially systemic, certain elements of shadow banking can lend themselves to amplifying shocks and generating systemic risk (not just outsized movements in market prices). The mechanisms by which this is possible can be traced back to the structural characteristics of, and motivations for, shadow banking. For instance, extensive risk transformations inherent in some shadow banking activities can act as stress accelerants and increase uncertainty premiums where the true nature of underlying risk is obscured; a high degree of interconnectedness opens up the path for stress transmission and cascade effects across institutions; ${ }^{15}$ the role of implicit sponsor backstops means that stresses experienced by some shadow banking entities can quickly metastasize into contingent liabilities for their sponsors, who may not have the capital or liquidity to absorb them; and the heavy reliance of some shadow banking vehicles on runnable forms of financing (including but not limited to wholesale markets) leaves them exposed to refinancing risk during periods of heightened risk aversion. The vulnerabilities associated with these structural features can be magnified under two conditions, where (1) intermediating agents are incentivized to exploit regulatory loopholes and asymmetric information; and (2) policymakers do not have adequate policy instruments to address them (at least not in a timely manner). Severing the adverse feedback loop may require the ultimate backstop-the sovereign balance sheet - to be deployed to put out the ensuing blaze. ${ }^{16}$ This is a contingency that may be available only at great cost.

\footnotetext{
${ }^{15}$ For instance, rehypothecation of collateral by lenders to a third party creates the lenders' bankruptcy risk in the sense that, if the lender defaults on his obligation to the third party, collateral is confiscated by the third party and the original borrower does not get it back, even if he is willing and able to fulfill his obligations (Muley 2016).

${ }^{16}$ One of the more notable examples was the deployment of a backstop by the US Treasury in response to the stresses occasioned by the Reserve Primary Money Market Fund "breaking the buck" after the Lehman failure.
} 



\section{Chapter}

\section{The Postcrisis Evolution}

Among the key changes to have unfolded in global patterns of NBCI since the financial crisis, two stand out. At the activity level, there has been a material swing away from the riskier elements of shadow banking. And, at the geographical level, NBCI activity in emerging markets has become increasingly prominent.

\section{Less "Toxic" Shadow Banking}

The first notable trend, most pronounced in advanced economies, has been a reduction in the types of so-called "toxic" shadow banking activities that amplified the effects of the global financial crisis. ${ }^{1}$ This has been reflected in a generalized "flight to simplicity and transparency" in the intermediation of nonbank credit, spurred by regulatory changes and a reorientation in intermediary business models (FSB 2017b).

Because data inconsistencies and definitional issues at the cross-country level make attempts at precisely quantifying the size of this shift problematic, two sets of data help to make the general point. ${ }^{2}$ By one measure-based on the FSB's Flow of Funds data - a roughly US $\$ 10$ trillion swing toward standard collective investment vehicles can be inferred between 2007 and 2015, and a US\$6 trillion to US\$7 trillion swing against all other types of nonbank credit intermediation, including some forms of undesirable shadow banking that created significant problems a decade ago (Figure 3.1). ${ }^{3}$ By another

\footnotetext{
${ }^{1}$ See: http://www.fsb.org/wp-content/uploads/P030717-1.pdf.

${ }^{2}$ Without the implication that either is perfect.

${ }^{3}$ It should be noted that non-Flow of Funds data do not point to a similar-sized decline in certain types of intermediation activities. For a discussion of changing patterns of collateral intermediation, see also Singh (2013).
} 
Figure 3.1. Global Nonbank Credit Intermediation, by FSB Economic Function Nonbank Credit Intermediation (FSB “Narrow” Measure) (Trillions of US dollars)

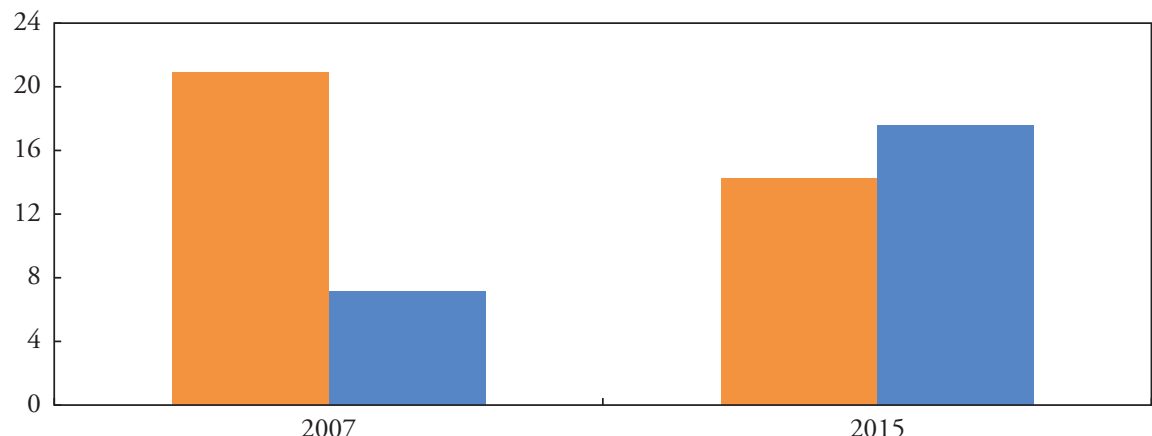

FSB Economic Functions 2-5: Other Nonbank Credit Intermediation (but including MMFs)

FSB Economic Function 1: Collective Investment Vehicles (but excluding MMFs)

Source: FSB 2017a; and IMF staff.

Notes: Economic functions (EFs) as per the "narrow" measure in Financial Stability Board (2017a), but with MMFs moved from EF1 to the EF2-5 grouping. EF1 = collective investment vehicles (fixed income funds, hedge funds, real estate funds, fund of funds, mixed funds, pooled funds, and other funds).

$\mathrm{EF} 2$ = finance companies, leasing companies, real estate credit companies, consumer credit companies, factoring companies, nonbank credit card issuers. EF3 = broker dealers and securities finance companies. $\mathrm{EF} 4$ = financial guaranty insurers, mutual guarantee societies, mortgage guarantee insurers, insurance corporations, loan guarantee co-ops. EF5 = asset-backed and structured finance vehicles.

measure - focusing exclusively on the US Flow of Funds-a broadly similar trend emerges. This is evident in the fact that assets intermediated through (relatively simple, insolvency-remote) collective investment vehicles like bond mutual funds and exchange-traded funds have more than doubled since 2007, while the assets of broker-dealers, finance companies, asset-backed securities issuers, and money market funds (MMFs) have almost halved (Figure 3.2).${ }^{4}$ Importantly, interconnectedness has also been reduced. In part, this reflects the emergence of shorter collateral chains. After all, collateral does not flow in a vacuum: it needs a balance sheet to move, and balance sheet space for key entities has become scarcer.

\section{Deepening in Emerging Markets}

A second emergent trend is the relative rise of NBCI activity in emerging market economies, consistent with the broader process of financial deepening. One (albeit imperfect) proxy for this can be seen in comparing the growth in assets of "other financial intermediaries" (OFIs) as compiled by the

\footnotetext{
${ }^{4}$ See Adrian, Boyarchencko, and Shachar (2017) for a discussion of these divergent trends in the context of broker-dealer intermediation of corporate bond trading. Note that this discussion is not intended to imply that the fast-growing activities of collective investment vehicles are divorced from risks (quite the contrary), only that they are of a nature that is different from those that surfaced a decade ago.
} 


\section{Figure 3.2. US Nonbank Credit Intermediation, by Vehicle Type}

US Nonbank Credit Intermediation (Select Measures)

(Trillions of US dollars)

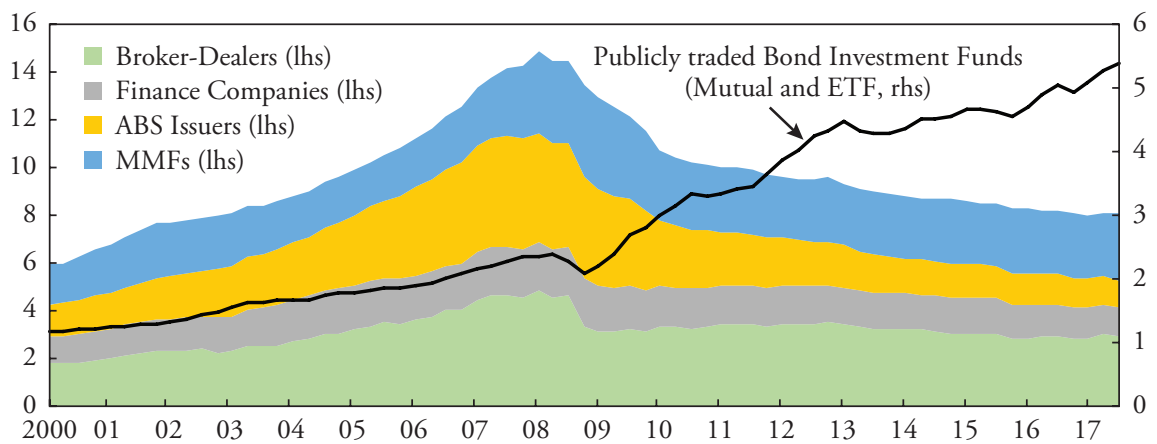

Source: Federal Reserve Board, Flow of Funds

Note: $\mathrm{ABS}=$ asset backed securities; $\mathrm{MMF}=$ money market funds; ETF $=$ exchange traded fund.

FSB,${ }^{5}$ where the emerging market share of the global total has increased from just 4 percent in 2011 to 11 percent in 2015. The upward trend has been observed both in China and across emerging markets more generally, while, among advanced economies, the United States and the United Kingdom have seen the largest relative declines. Different data sets point to broadly similar trends in the relative growth of NBCI in emerging market, such as noncore liabilities (IMF 2014), and MMF assets (Figure 3.3), where the emerging market share of the global total has increased from 7 to 20 percent since

\section{Figure 3.3. Share of Worldwide Money Market Fund Assets}

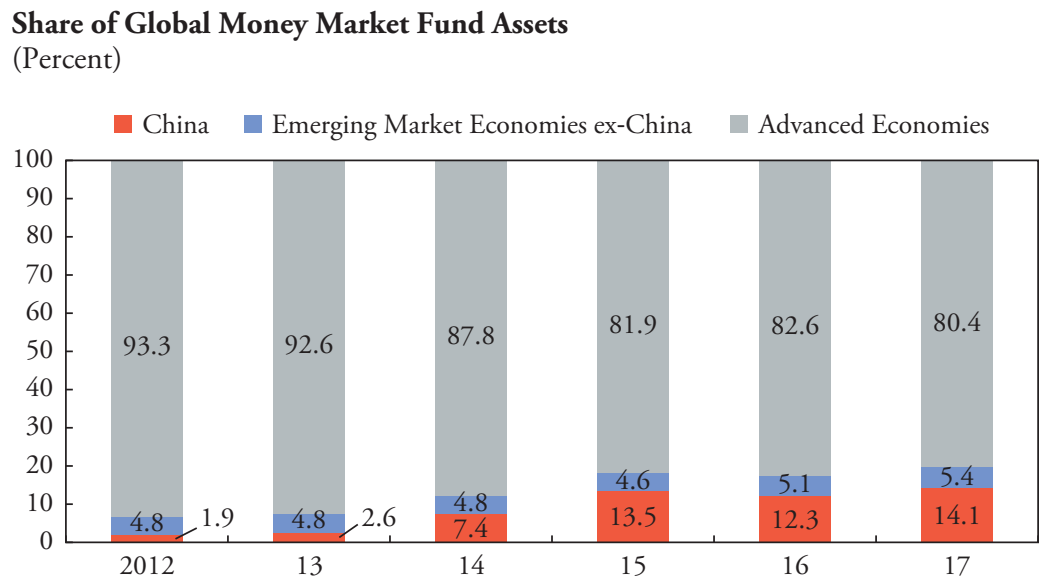

Source: European Fund and Asset Management Association.

\footnotetext{
${ }^{5}$ This measure includes financial system assets outside those held by banks, central banks, public financial institutions, insurers, pension funds, and financial auxiliaries.
} 
2012 (largely accounted for by Constant Net Asset Value Money Market Funds [CNAV MMFs] in China). One implication, addressed further in the next chapter, is that, as NBCI in emerging market economies continues to increase in size and scope, ensuring that regulation and supervision are globally coordinated will take on increasing importance. 


\section{ChAPTER}

\section{Strengthening Supervision and Regulation}

\section{Taking Stock of Progress}

Since the crisis, a concerted policy effort has been undertaken to strengthen the regulation and oversight of NBCI, with the aim of promoting more resilient forms of market-based finance. This effort has found expression in a variety of initiatives. Having designated shadow banking as one of its priority areas, the FSB has created a system-wide monitoring framework to track developments in the global shadow banking system, with a view to identifying the buildup of systemic risks and initiating corrective actions where necessary. The annual Global Shadow Banking Monitoring Report is a feature of this work. In Europe, the European Systemic Risk Board (ESRB) has begun a mapping of the European Union's shadow banking system, which feeds into the ESRB's Risk Dashboard, internal risk assessment processes, and the formulation and implementation of related macroprudential policies. The IMF has been similarly engaged, by intensifying its supervision under the auspices of bilateral Financial Sector Assessment Programs and Article IV Consultations, in addition to its multilateral surveillance work featured in the Global Financial Stability Report (see, for instance, IMF 2014, 2015).

While an exhaustive review of all related regulatory reforms is beyond the scope of this paper, ${ }^{1}$ a few elements of the reform agenda deserve mention in the context of the evolving NBCI landscape. Among the most consequential have been the Basel III reforms, designed in part to ensure better recognition and capitalization of banks' explicit and contingent exposures to shadow banking entities. Largely as a result, the off-balance-sheet provision of credit insurance by deposit-taking institutions has declined, helping to reverse the precrisis trend of growing interconnectedness between the traditional and shadow banking systems. Other import-

${ }^{1}$ Useful recent reviews can be seen in FSB (2017b, 2017e). 
ant shadow banking reform priorities have focused on dampening risks associated with securities financing transactions and over-the-counter derivatives. These have included, for instance, reducing liquidity mismatches arising from nonbanks' use of securities financing transactions, constraining excessive buildup of nonbank leverage with the imposition of haircuts on non-centrally-cleared securities financing transactions, and reducing risks in over-the-counter derivatives and triparty repo markets through market infrastructure reforms. With many of these efforts continuing, it is still too early to judge their effectiveness. Nevertheless, it is possible to draw attention to two examples of shadow banking activities that caused significant problems during the crisis, but that, by virtue of regulatory reforms, have since been placed on a sturdier footing: MMFs and securitizations.

Dampening the financial stability risks associated with MMFs (and CNAV MMFs in particular) has been a priority. Although they are relatively simple vehicles, the centrality of CNAV MMFs in the crisis stemmed from two structural features. First, they issued runnable bank-like liabilities that were redeemable at par on demand, to fund portfolios of assets with credit risk, lower liquidity, and longer maturity. Second, by virtue of their sheer size and the structure of the asset-liability mix, MMFs were strongly connected to the commercial banking system on both sides of the balance sheet - through implicit sponsor insurance lines on the liability side (aimed at preventing MMFs from breaking the buck), and, on the asset side, through repo exposure and their holdings of bank paper and deposits. From a spillover perspective, these structural vulnerabilities were not just confined within domestic borders: the run on US MMFs created significant financing problems for banks in Europe when the former were subjected to large-scale redemptions (see Baba, McCauley, and Ramaswamy 2009).

These vulnerabilities have prompted a range of subsequent reforms. In the United States, which accounts for about 60 percent of global MMF assets, prime institutional MMFs are now required to "float their NAV" (that is, to no longer guarantee investors redeemability at par); nongovernment MMF boards have been equipped with new tools (liquidity fees and redemption gates) to more effectively deal with the first-mover-advantage problem; financial disclosure requirements have been strengthened to reduce investor uncertainty; and, critically, bank sponsors are now required to more heavily capitalize their MMF support lines. These reforms have culminated in a significant shift away from prime institutional MMFs, which some investors assumed were providing something for nothing-risky-asset returns, without the risk (Figure 4.1). And in Europe, similar sets of regulations are soon set to take effect. These measures entail variable NAV pricing for some 
Figure 4.1. US Money Market Fund Assets

(Trillions of US dollars)

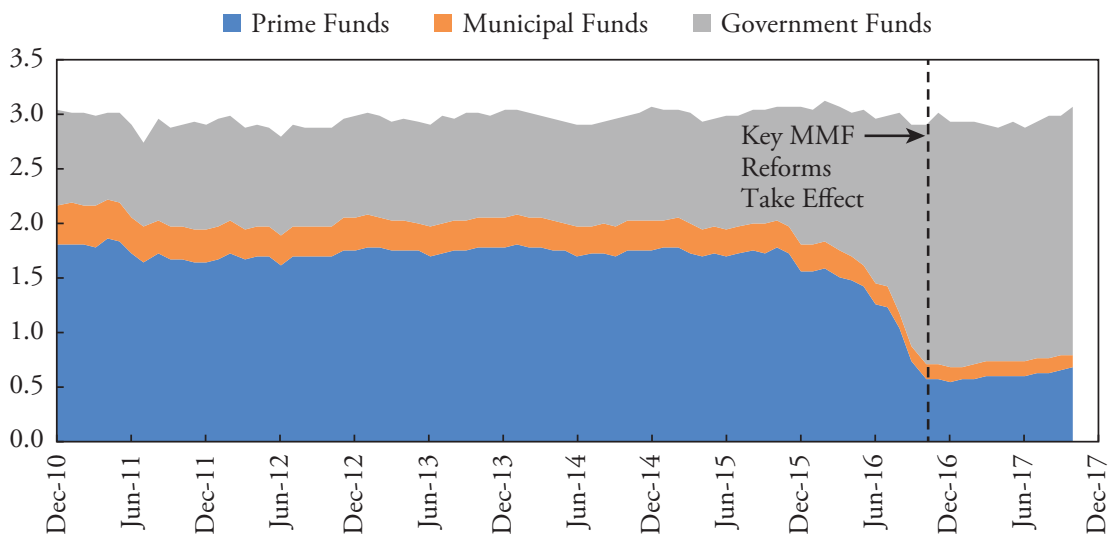

Source: Haver; and US Securities and Exchange Commission.

(nonsovereign) MMFs, new redemption fee and gating provisions, increased liquidity and diversification requirements, and a prohibition on MMF sponsor support.

The key role of particular forms of securitization activity in amplifying the crisis has also been a focus for regulators. Where credit risk transformation was motivated by regulatory arbitrage and misaligned incentives, amplified by neglected tail risk, and abetted by mispriced backstops that had significant spillover implications for the insurance providers, the effects were devastating. It was not just in the United States where securitization markets took on a very different complexion in the precrisis period compared to earlier decades. In Europe, annual securitization issuance soared from less than US\$100 billion in 1999 to US\$1.2 trillion at the 2008 peak, most of which comprised residential mortgage-backed securities (Segoviano and others 2015).

As with the MMF landscape, securitization markets have since been overhauled. Loan underwriting standards have been strengthened; the scope of prudential consolidation has been expanded to require banks that sponsor securitization vehicles to hold regulatory capital against these exposures; information disclosure requirements have increased; and credit retention requirements - popularly known as "skin in the game" - have been introduced to better align the incentives of originators and investors. ${ }^{2}$ As a result,

\footnotetext{
${ }^{2}$ In the EU, retention rules were put in place in January 2011 (and revised in 2014) that allowed investor financial institutions to assume exposure to a securitization only if the originator, sponsor, or original lender has explicitly disclosed to the institution that it will retain, on an ongoing basis, a material net economic interest of at least 5 percent. In the United States, risk retention rules now require securitization issuers or sponsors to retain an economic interest of at least 5 percent of the aggregate credit risk of the collateralizing assets (since
} 
Figure 4.2. "Riskier" US Residential Mortgage-Backed Securities

Combined Subprime, Alt-A, HELOC, and Junior Lien RMBS

(Billions of US dollars)

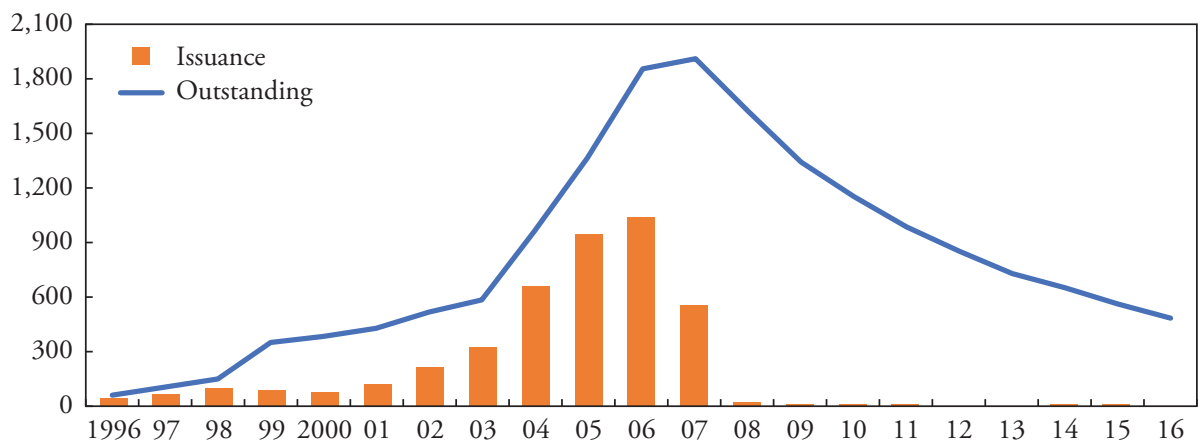

Source: SIFMA.

Note: $\mathrm{HELOC}$ = home equity line of credit; RMBS = residential mortgage backed security.

the issuance of riskier types of residential mortgage-backed securities-known in the United States as subprime, Alt-A, Home Equity Lines of Credit, and Junior Liens - has all but ceased, having previously topped out at just over US\$1 trillion in 2006 (Figure 4.2). Reforms have also been directed to increasing the transparency and standardization of securitization products, ${ }^{3}$ a direct response to the opaqueness and complexity that came to characterize securitization innovations (for example, synthetic CDOs) in the precrisis period.

Reforming the practices credit rating agencies (CRAs) has also featured in the regulatory response to the crisis. ${ }^{4}$ In the case of the United States, which is home to the major CRAs, the US Securities and Exchange Commission adopted in 2014 a range of reforms aimed at addressing internal controls, conflicts of interest, disclosure of credit rating performance statistics, procedures to protect the integrity and transparency of rating methodologies, disclosures to promote the transparency of credit ratings, and standards for training, experience, and competence of credit analysts. The requirements provide for an annual certification by a CEO of the effectiveness of internal controls and additional certifications to accompany credit ratings attesting that the rating was not influenced by other business activities. The commission also adopted requirements for issuers, underwriters, and third-party due-diligence services to promote the transparency of the findings and conclusions of third-party due diligence regarding asset-backed securities.

December 2015 for securitization transactions backed by residential mortgage loans, and since December 2016 for all other asset-backed securities).

${ }^{3}$ This requires both intermediating banks and credit rating agencies to disclose far more information about underlying loan pools and the assumptions used to arrive at credit rating assessments.

${ }^{4}$ See FSB (2010) for an early example at the global level. 


\section{Outstanding Priorities}

Nevertheless, this is not to suggest that the job is done. As acknowledged in recent FSB analysis, implementation of the Policy Framework for Shadow Banking Entities remains at a relatively early stage (FSB 2016, 2017b). There are still lingering questions about whether some of the earlier-discussed economic motivations for shadow banking activities have been fully addressed, and whether risk has simply shifted toward corners of the financial system where policymakers have less visibility and fewer instruments to deploy. This is grounds for caution, given that systemic risk stems, at least in part, from market failures such as moral hazard, information frictions, agency problems, and coordination failures that afflict large institutions (see, for instance, Adrian, Covitz, and Liang 2013).

The issues of information asymmetries and agency problems are instructive in this regard. While some precrisis behaviors that exploited informational asymmetries and misaligned incentives in the mortgage market have been at least partially addressed, other incentive problems have proven more challenging to overcome. As a case in point, CRAs still overwhelmingly operate under the "issuer pays" model, in which incentives exist to assign more favorable ratings than warranted in order to win business. ${ }^{5}$ Notwithstanding recent reforms, the potential for conflicts of interest to influence the ratings process remains most acute for structured finance products where information asymmetries, barriers to entry, and, thus, profit margins are highest (Securities and Exchange Commission 2016). A number of proposals that could potentially make a difference to the CRA business model have yet to be decided upon. ${ }^{6}$ In addition, while many countries have taken steps to reduce the mechanistic reliance of investors on CRA ratings, some elements of the Basel III capital rules continue to be based on them (see FSB 2017a and Bank for International Settlements 2016).

Other incentive-related issues in structured finance have proven similarly difficult to iron out, with the result that regulatory arbitrage remains a persistent threat, including at the cross-border level. For instance, many coun-

\footnotetext{
${ }^{5}$ Some researchers have suggested that excessive regulatory reliance on ratings and the increasing importance of risk-weighted capital in prudential regulation have more likely contributed to distorted ratings than the matter of who pays for them, particularly in light of the fact that, for a century prior to the global financial crisis, CRAs were viewed by regulators and investors as valuable independent agents in the financial system (see Cole and Cooley 2014). However, many countries have since taken steps to reduce the mechanistic reliance on CRAs in their laws and regulations.

${ }^{6}$ Without passing judgment on their potential effectiveness, proposals along these lines have included having investors contribute some share of the cost of CRA fees when they purchase rated products, making CRAs legally liable for their ratings in a manner similar to an accounting firm or securities analyst, empowering an independent body to assign CRAs to rate structured products to reduce ratings shopping, and distinguishing the credit rating system for structured products from corporate bonds. See also Rivlin and Soroushian (2017).
} 
Figure 4.3. US Mortgage-Backed Securities: Agency versus Nonagency

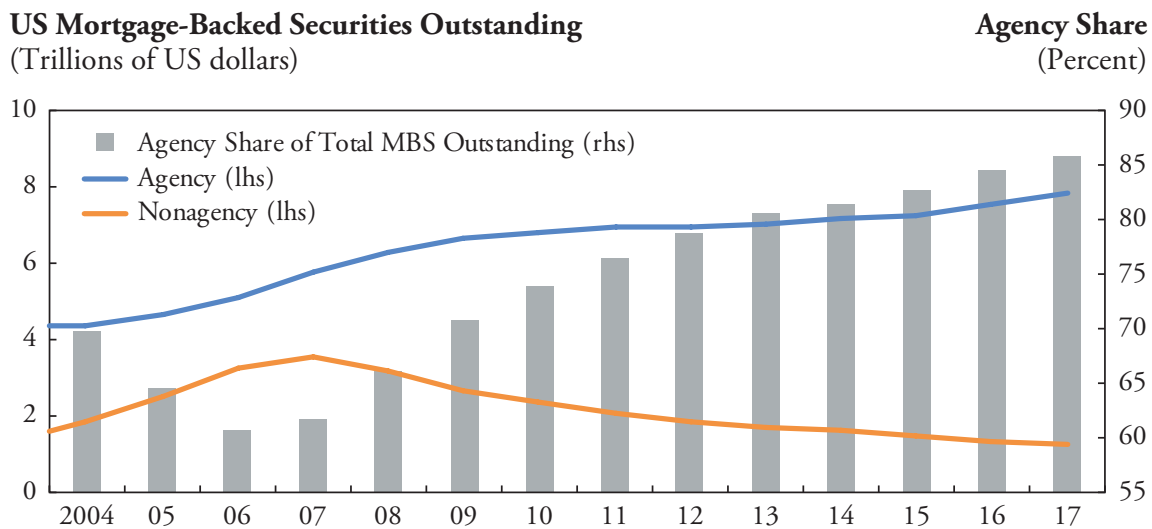

Source: SIFMA.

tries outside the EU and the United States either have yet to put into effect skin-in-the-game rules or have maintained exemptions that can dilute their effectiveness (IOSCO 2015). There has also been only limited use of tools to address cross-border impacts in regimes where incentive alignment requirements governing securitization activity have been introduced (IOSCO 2015). In addition, even in the two largest markets for structured finance, there are questions about whether the coverage of new retention rules has been adequate. ${ }^{7}$ More broadly, the prospect of cross-border regulatory arbitrage continues to loom large in securities financing transactions where reforms enacted in the United States have not been replicated elsewhere. ${ }^{8}$

As to the issue of mispriced implicit backstops-one of the key features of riskier forms of shadow banking - progress here has also been mixed. Supervisory guidelines to address banks "step-in risks" for noncontractual and reputational exposures will only be implemented in 2020. In the United States, reform of the US government-sponsored enterprises appears to have stalled at a time when their share of mortgage-backed securities activity has expanded to 86 percent, up from 61 percent in 2006 (Figure 4.3). The issue of implicit backstops has also become more pressing in some larger EMs, where all forms of NBCI, including shadow banking activity, are growing most briskly.

\footnotetext{
${ }^{7}$ In the European Union, products that are guaranteed by governments and public institutions are generally exempt from retention requirements, as are some products guaranteed by certain regulated financial institutions. In the United States, meanwhile, securitizations related to some government programs are also exempt from incentive alignment requirements, along with securitizations considered to have met high-quality underwriting standards or otherwise considered in the public interest (IOSCO 2015).

${ }^{8}$ These reforms have culminated in the supervision of the two key triparty service providers and a substantial reduction in potential financial stability risks associated with repo market infrastructure. For example, the share of triparty repo volume that is financed with intraday credit from a clearing bank has declined from 100 percent as recently as 2012, to about 5 percent more recently (FSB 2017b).
} 
And although regulators are now striving to create an enabling environment to better support the issuance of higher-quality, more standardized, and more transparent securitizations as a means of contributing to a healthier overall credit mix (see, for instance, Bank of England and European Central Bank 2014 and European Banking Authority 2014, 2015), the market response has generally been less than hoped for. Revitalized securitization markets could play a more prominent role in addressing Europe's nonperforming-loan overhang, for instance (Aiyer and others 2015). 



\section{ChAPTER}

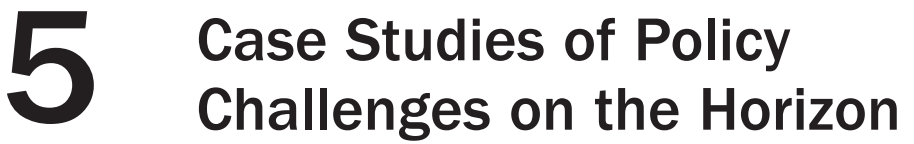

In addition to completing the global reform agenda, policy authorities will almost certainly have to contend with new homegrown challenges in the years ahead. Although this is by no means an exhaustive list, four examples are discussed in this chapter: managing the rise of NBCI in China, navigating the partial return of structured leveraged finance in the United States, addressing the data-related challenges in European asset management supervision, and stepping up the monitoring of new financial technologies (FinTech) in both advanced and emerging market economies.

\section{Credit Intermediation in China}

Fueled by a high savings rate and liberalizing reforms, China's financial system, and its system of credit intermediation in particular, has become more inclusive and has facilitated remarkably high and stable growth rates over a long period of time. However, in more recent years, the emergence of a relatively high credit-to-GDP ratio and a large credit gap ${ }^{1}$ — the product of rapid credit intermediation both within and outside the traditional banking system-has attracted increasing attention from policymakers. Select NBCI activities have expanded by about 100 percent of GDP since 2010 (Figure 5.1), a faster rate of expansion than traditional bank loan growth. ${ }^{2}$

Aside from simply the sheer volume and rapid growth of credit in China, certain features of NBCI activities are noteworthy in the context of the framework introduced earlier. Extensive risk transformations are an important feature of NBCI in China, notably, credit enhancement and liquidity transformation. For instance, investors tend to perceive the expected returns dis-

\footnotetext{
${ }^{1}$ The credit gap is measured as the deviation of the credit-to-GDP ratio from its long-term trend.

${ }^{2}$ See also the 2017 Article IV Consultation and Financial System Stability Assessment for China.
} 
Figure 5.1. Nonbank Credit Intermediation in China

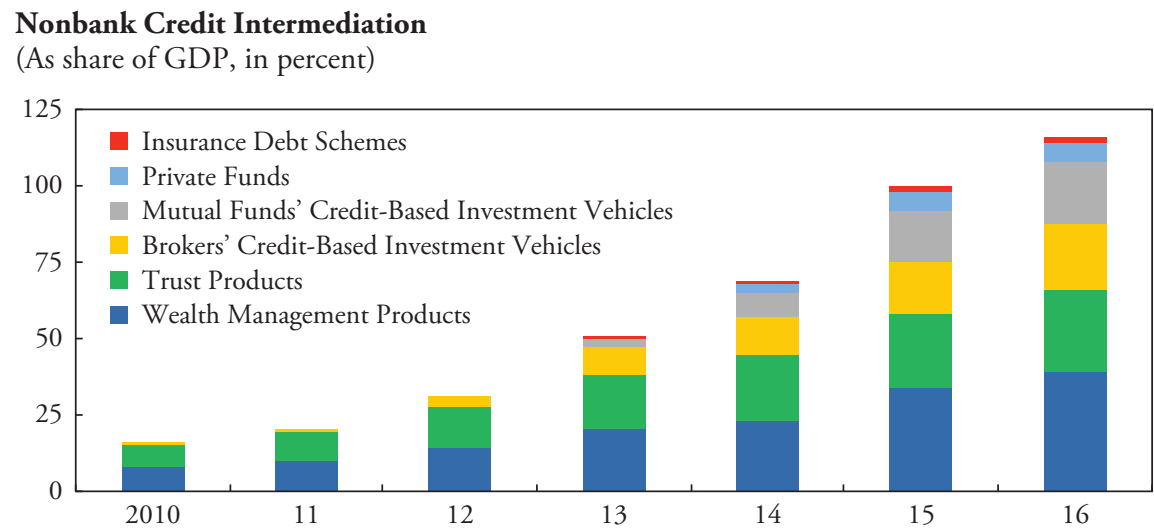

Sources: CEIC; China Trustree Association; and IMF staff calculations.

cussed in investment prospectuses — which comfortably exceed those available on bank deposits - as conferring certain returns, even though the price of the underlying collateral that is backing such products (often corporate loans) is time-varying and embedded with credit risk. These perceptions may be hardened by the unusually high proportion of securities and financial products that are assigned a AAA credit rating by China's domestic credit rating agencies. Additionally, credit intermediation in China, both inside and outside the traditional banking sector, is increasingly financed through short-term wholesale borrowing. Some of these risk transformations have taken place across an increasingly interconnected and complex intermediation chain. Bank claims on other financial institutions have risen from less than 30 percent of GDP in 2010 to more than 130 percent currently (Figure 5.2). As a share of their total assets, bank claims on nonbank financial institutions have doubled over the past decade to 25 percent, and their funding dependency on nonbanks has also risen notably. Furthermore, complexity and opacity in the shadow banking system have been exacerbated by the numerous stages of loan channeling and layering of leverage, which makes "seeing through" to the risks of the underlying asset more difficult to assess for both investors and regulators. ${ }^{3}$

As to the issue of official backstops, because the balance sheets of deposit-taking banks have become more closely intertwined with those of nonbank financial institutions, the latter have greater scope to avail themselves, indirectly, of the benefit from the official-sector backstops-access to central bank liquidity and deposit insurance-that are only formally available to traditional banks. It is notable that many large nonbank financial institutions in China belong to the same financial holding group as traditional banks.

\footnotetext{
${ }^{3}$ See both the 2017 Article IV Consultation and Financial System Stability Assessment for China.
} 
Figure 5.2. Depository Institution Claims on Other Financial Institutions in China

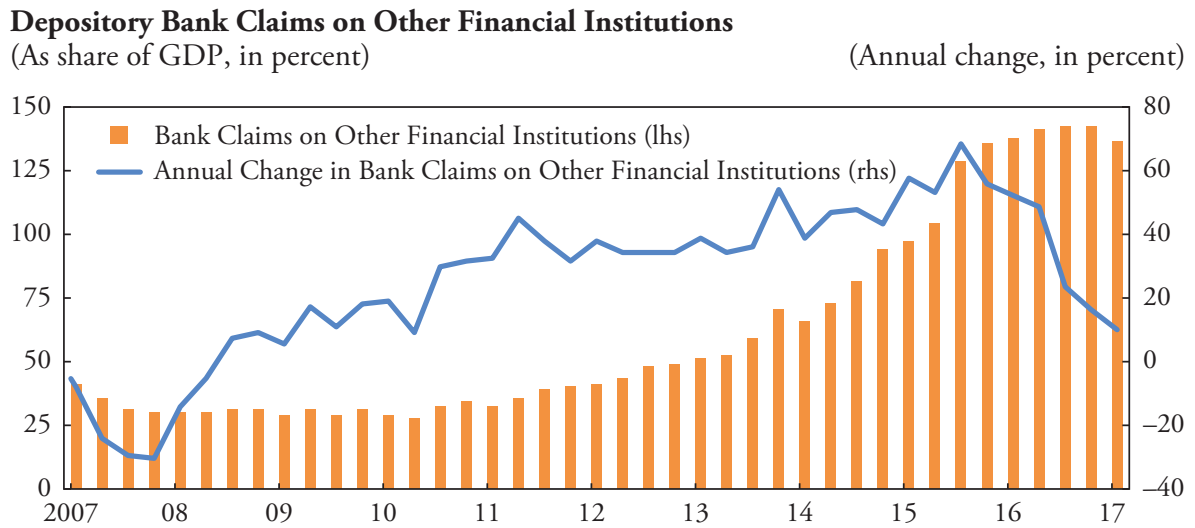

Sources: People’s Bank of China; and Haver.

Although the growth of some forms of NBCI in China simply reflects the process of financial deepening from a low base, there are instances where the motivations for these activities are potentially more problematic when viewed through a financial stability lens. For instance, in the case of regulatory arbitrage, the capital charges imposed on banks for holding AAA-rated tranches of loan securitizations can be as little as one-quarter of those associated with retaining the underlying loans themselves, which may reduce the overall capital required to support all the tranches of the securitizations. By selling these loans to off-balance-sheet vehicles and recategorizing their economic exposure as investment claims, banks are afforded capital relief and are also able to circumvent regulatory ceilings on loan volumes. Agency frictions and implied sponsor support can be similarly powerful motivators for NBCI activity. As a case in point, reputational concerns mean losses incurred on wealth management products - which are mostly off-balance-sheet and thus solvency-remote-might ultimately need to be absorbed by the distributing bank, given the preponderance of implicit guarantees.

China's MMF industry — now the world's second largest, and about half the size of the domestic fund management industry - offers a simple yet vivid illustration of many of these themes. First, it is rapidly growing outside the regulatory perimeter of the standard investment fund industry. For instance, Yu'E Bao, whose assets of about US $\$ 200$ billion make it the largest MMF in China and among the largest in the world, is offered through Alipay, an affiliate of e-commerce firm Alibaba. Second, China's MMF vehicles are almost exclusively of the CNAV variety, meaning they offer redeemability on demand at par, which is at odds with the global trend toward flexible pricing for nonsovereign MMFs. Third, even after recent reductions, the maximum weighted average maturity of China's MMF portfolio holdings (120 days) 
is still twice that of most MMFs in the United States and Europe, with the attendant risk of liquidity mismatches given that cash holdings have declined from about 75 percent in 2013 to less than 50 percent more recently (see McLoughlin and Meredith 2017). Furthermore, MMF borrowing is largely provided via commercial bank repos_- a contrast with most countries, where MMFs typically act as lenders, not borrowers, in the repo market. This leaves them susceptible to a funding shock that might emanate from the banking system. Fourth, Chinese MMFs are also able to use significant volumes of leverage, meaning that MMF net assets of a little more than US $\$ 500$ billion actually equate to about US\$1 trillion of gross asset holdings. This, again, is rather unusual by global standards, in that the use of leverage by MMFs is typically prohibited or is at least heavily constrained. ${ }^{4}$

Encouragingly, policymakers have recently taken a number of steps in response to the associated vulnerabilities. Most notable in this regard have been efforts to close down avenues for arbitrage between the traditional and nontraditional banking sector, a strengthening of the enforcement of existing regulations, and a gradual unwinding in the presumption of sponsor support for wealth management products. Some of these efforts are bearing fruit, as shown by the sharp slowdown in bank claims on nonbank financial institutions (Figure 5.2) and off-balance-sheet wealth management products. Nevertheless, continued careful sequencing of reforms will be critical in facilitating an orderly adjustment in NBCI activity toward more sustainable modes of financing. 5

\section{Structured Leveraged Finance in the United States}

While far fewer subprime mortgage loans are now issued and securitized, and complex securitizations have declined in scale and scope, select areas of the US structured finance markets have become notably buoyant in recent times. This is particularly evident in new issuance and pricing patterns in relatively low-rated leveraged and subprime auto loans.

In the case of the leveraged loan market, new issuance has set a record over the past year, and outstanding volumes are now more than 50 percent above the 2008 peak (Figure 5.3). The share of loans at the riskier end of the rating distribution $(\mathrm{B}+$ or below) has reaccelerated to near-record levels

\footnotetext{
${ }^{4}$ Gearing has risen over time, on one measure from less than 20 percent in 2007 to about 50 percent more recently (McLoughlin and Meredith 2017), although more punitive limits on leverage have recently been introduced.

${ }^{5}$ See the 2017 Financial System Stability Assessment for China for more details.
} 
Figure 5.3. US Leveraged Loans: Outstanding Volume and Spreads

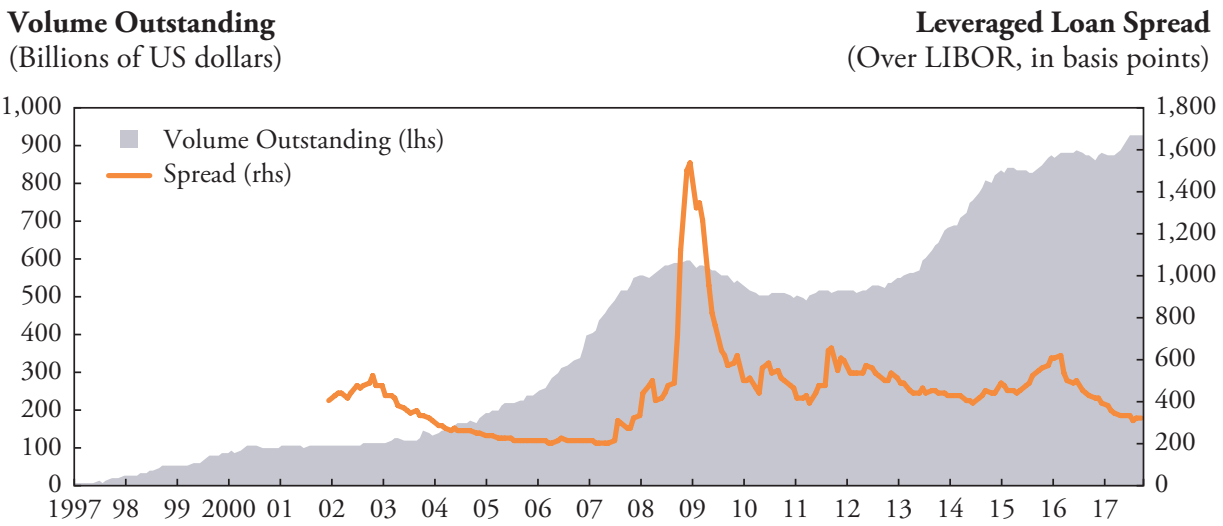

Source: S\&P LCD

(Figure 5.4), along with the covenant-lite share. ${ }^{6}$ This debt has increasingly been raised for the purposes of funding leveraged buyouts and other types of procyclical merger and acquisition transactions, and is consistent with the average debt/EBITDA multiple on leveraged loans also making new highs (Figure 5.5). In response to the decline in underwriting standards, a higher share of loans is now being downgraded, and default rates are picking up. ${ }^{7}$ Yet spreads remain at the low end of their historical range. Similar dynamics can also be observed in other areas of leveraged finance, such as the high-yield bond market.

Nevertheless, while these developments suggest that investors may be accepting risk premiums that are unusually low by historical standards, it is not clear that a repricing would have systemic implications in anything like the manner of the subprime mortgage crisis. One simple reason is that, despite its rapid growth, the leveraged loan market is still only equivalent to about 5 percent of US GDP and, in absolute terms, is half the size of the subprime mortgage market at its peak. ${ }^{8}$ Another is that the distribution of leveraged loan exposure across investor types is better calibrated to risk absorption

\footnotetext{
${ }^{6}$ Apart from a deterioration in lending standards, a high "Cove-lite" issuance share could reflect other developments, such as an increase in the quality of the borrower pool and/or the rising share of institutional investors (who are less likely to make use of covenants) in the leveraged loan market. For a review of financial stability-relevant information that can be reflected in both price and nonprice terms in credit markets, see Stein (2013a) and Jones (2016).

${ }^{7}$ Historically, defaults on leveraged loans have closely tracked macroeconomic and financial conditions, with default rates a little lower than high-yield bonds (in the range of 1 percent and 12 percent annually) and recovery rates much higher (about 70 percent, reflecting the fact that leveraged loans are typically collateralized and senior to other debt instruments).

${ }^{8}$ The European leveraged loan market has also exhibited some of the trends observed in the United States, although it is about one-fifth the size.
} 
Figure 5.4. US Leveraged Loans: Issuance of Lowly Rated Debt (B-Rated or Lower)

US Leveraged Loan Issuance: Single-B-Rated or Lower

(As a share of total issuance, in percent)

(Billions of US dollars)

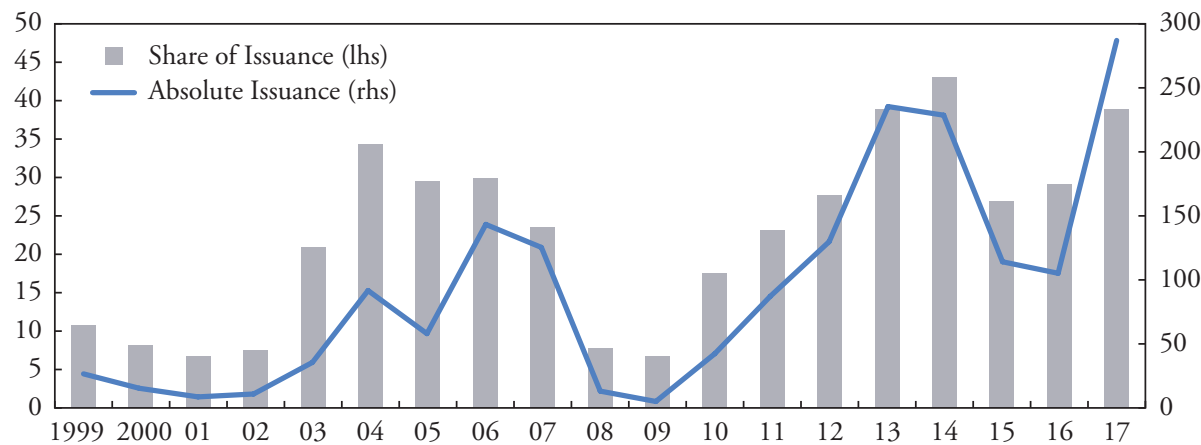

Sources: S\&P LCD; and IMF staff calculations.

Note: Figure for 2017 is annualized based on the first half of 2017.

capacity than was the case for subprime mortgages. For instance, the bank share of leveraged loans has declined from about 25 percent a decade ago to less than 10 percent now, a trend that may have been at least partly reinforced by stricter guidance issued by financial regulatory agencies in $2013 .{ }^{9}$ Dedicated institutional investors that manage pass-through vehicles like distressed debt, hedge and private equity funds now play a more active role, and, although these vehicles bring their own risks, ${ }^{10}$ they typically have redemption run, ${ }^{11}$ solvency, and interconnectedness risk characteristics that

\footnotetext{
${ }^{9}$ The agencies involved included the Office of the Comptroller of the Currency, the Board of Governors of the Federal Reserve System, and the Federal Deposit Insurance Corporation. Guidance outlined the agencies' minimum expectations on a range of topics related to leveraged lending, including underwriting and valuation standards, pipeline management, risk ratings, and problem credit management. See http://libertystreeteconomics.newyorkfed.org/2016/05/did-the-supervisory-guidance-on-leveraged -lending-work.html.

${ }^{10}$ In the context of the rising influence of institutional investors in the leveraged loan market, collateralized loan obligation (CLO) funds have become prominent. Although CLOs have generally performed well (vis-à-vis corporate credit and other structured finance products) over recent decades (see S\&P Global Ratings 2014), their rapid recent growth and high rates of embedded leverage should keep regulators attuned to related stability risks.

${ }^{11}$ Liquidity risk is potentially of greater concern in the case of leveraged loan mutual funds and ETFs (which hold about one-fifth of total leveraged loan exposure), because the underlying loans often do not have the same liquidity profile as fund share units. But there has been limited analysis of whether liquidity risk in this market segment could have broader (systemic) implications. In a review of the role of authorized participants as both dealers and arbitrageurs in fixed-income ETFs that can be prone to liquidity mismatches, Pan and Zeng (2017) suggest authorized participants may strategically use ETF creations and redemptions to unwind their bond inventory imbalances in periods of liquidity stress. While these actions could prolong or even worsen NAV-based pricing divergences, the implications were tied more to market efficiency and limits-to-arbitrage than to systemic risk.
} 
Figure 5.5. US Leveraged Loans: Issuance of Lowly Rated Debt (B-Rated or Lower)

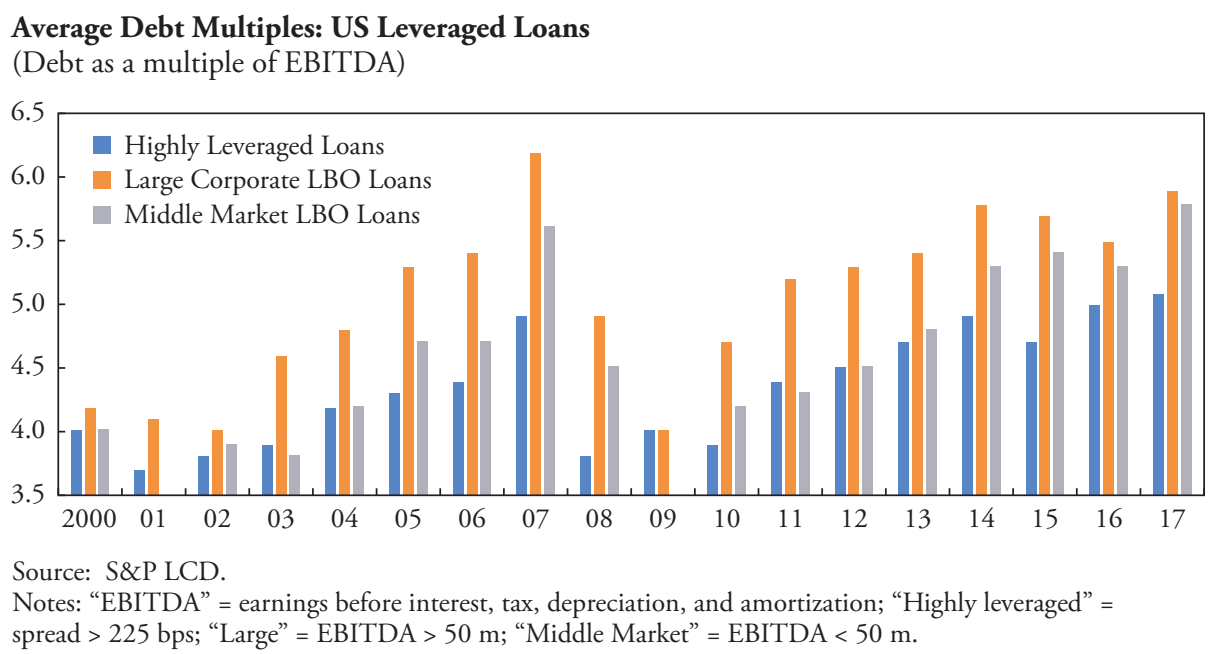

are somewhat more moderate than was the case for banks with subprime mortgage exposure.

A broadly similar set of dynamics appears to be at play in the US subprime auto-loan asset-backed securities market, with implications that are more sector-specific than systemic. The subprime loan share of the total auto-loan market is rising strongly, with $\$ 110$ billion of subprime auto loans issued in 2016 alone. Growth in auto-loan ABS issuance has followed suit, with the subprime share of auto-loan ABS also accelerating to a new high (Figure 5.6). Accompanying the rise in lower-credit-quality auto loans and subprime auto-loan ABS, delinquency and loan-loss rates are now rising. However, there is less scope for sizable forecast errors on auto-loan collateral values compared to the housing market, given the fact that the boom-and-bust nature of home price cycles has no equivalent in the auto sector. Moreover, the relatively modest volumes involved - the stock of subprime auto-loan ABS stands at about $\$ 50$ billion (0.3 percent of GDP) - means that the associated vulnerabilities remain sector-specific, not systemic. Nevertheless, the re-emergence of NBCI fueled by relatively lower-quality loans is a timely reminder that, because financing activity at the sectoral level continues to evolve, monitoring efforts need to stay attuned to new risks.

\section{European Asset Management}

The possible risks to financial stability posed by the largest segment of market-based finance, the asset management industry, have attracted much 
Figure 5.6. Subprime Auto-Loan Asset-Backed Securities

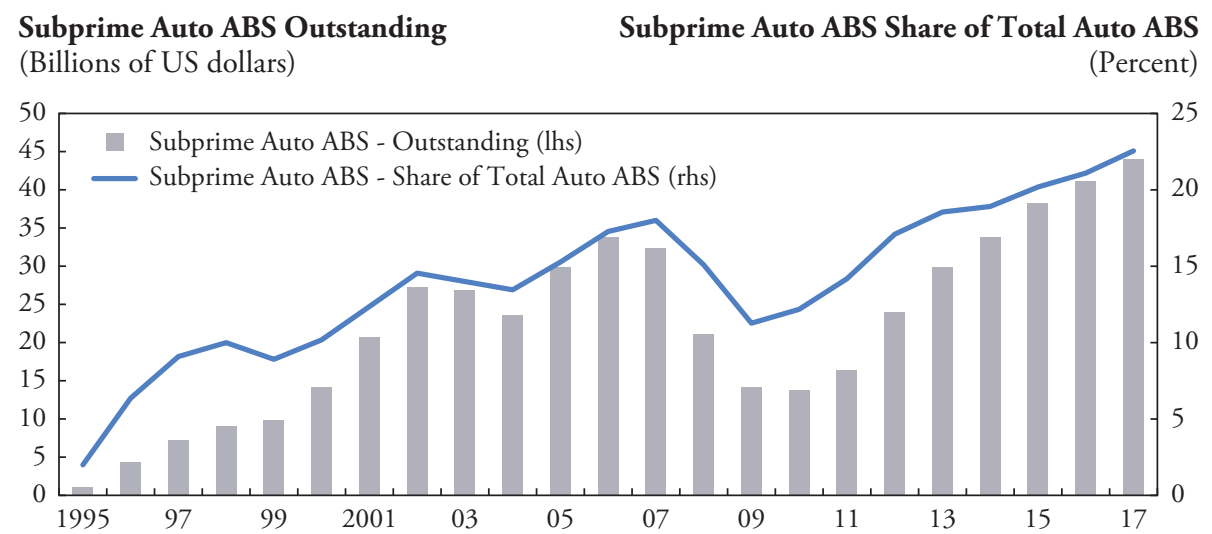

Source: SIFMA.

attention in recent years. After a lengthy consultation process, the FSB recently issued a set of policy recommendations to address structural vulnerabilities arising from asset management activities, relating particularly to liquidity transformation by investment funds, leverage within funds, operational risk and challenges in transferring investment mandates in stressed conditions, and securities lending activities of asset managers and funds (FSB 2017d). Recent Financial Sector Assessment Programs (FSAPs) have also taken stock of these risks in a bilateral context. ${ }^{12}$

The asset management industry presents some unique policy challenges and, from the standpoint of financial stability, is a greenfield area compared to banks. Even though collective investment vehicles like mutual funds have been in existence for decades, the emphasis of regulation and supervision has traditionally been focused on consumer protection, not system-wide financial stability. And because asset managers are fundamentally different from banks - they are highly heterogenous, they typically act in an agency capacity rather than as principals, their vehicles are generally insolvency remote, and they cannot avail themselves of an official backstop-the prudential policy framework developed for banks cannot be imposed on asset management firms or their activities. In addition to those issues raised in the recent FSB consultation (see earlier discussion), issues like the macroprudential effectiveness of liquidity management tools, ${ }^{13}$ the potential role of central banks

\footnotetext{
${ }^{12}$ In a European context, Luxembourg, Ireland, the United Kingdom, Sweden, and the Netherlands are recent examples.

${ }^{13}$ Liquidity management tools include redemption gates, fees, swing pricing, and other measures designed to ameliorate first-mover advantage. The topic of liquidity stress testing for investment funds has also been addressed in recent FSAPs.
} 
as market makers of last resort, ${ }^{14}$ and the macroprudential targeting of asset owners rather than just asset managers (see, for instance, Shleifer and Vishny 1997, Wurgler 2010, Haldane 2014, and Jones 2015), are just some of the areas of continuing analysis.

However, an informed assessment of potential stress amplification mechanisms first requires policymakers to have the right type of data. On this front, much remains to be done. While data gaps are common to all jurisdictions, three are highlighted below in the case of Europe's Undertakings for Collective Investment in Transferable Securities (UCITS) industry, which increasingly represents the most widely recognized and widely adopted legal form of collective investment around the world. ${ }^{15}$ First, it is difficult for supervisors to know the composition of fund unit liabilities once they are distributed by intermediaries (that is, whether the beneficial owners are concentrated by geography or investor type), and thus to know whether some funds are more vulnerable than others to synchronized runs. Second, the manner in which leverage data are collected in the funds management industry also makes it difficult to distinguish gross from net exposure, and whether derivatives are used for hedging or speculative purposes. These are not mere accounting semantics, but rather are quite fundamental to any assessment of possible risk accelerants. And more broadly, for special purpose vehicles established for activities other than securitization, information available to European supervisors has also been limited, as these vehicles have typically resided just outside the regulatory perimeter. ${ }^{16}$ Encouragingly, European authorities now have a number of initiatives in train to help address these gaps. For instance, efforts are underway to provide more clarity on the categories of beneficial owners and the use of leverage by investment funds. But a sustained and coordinated effort will be required to allow policymakers to collect and categorize data in a way most helpful in macro-financial surveillance.

\section{FinTech}

Any discussion of the financial stability risks posed by FinTech is made inherently challenging by virtue of the limited availability and comparability

\footnotetext{
${ }^{14}$ On central bank reaction functions in this respect, see, for instance, King and others (2017), Dobler and others (2016), and Bank for International Settlements (2014).

${ }^{15}$ It is important to note that it is the global reach of the European UCITS regime that motivates its inclusion in the discussion here, not because the issues cited are unique to it. Indeed, the relative rigor of the UCITS regulatory regime is why it enjoys global support. For instance, UCITS are now available for distribution in non-EU countries as far afield as Switzerland, Hong Kong, Singapore, Taiwan, Chile, Peru, Bahrain, South Africa, and Japan.

${ }^{16}$ Although these entities sit outside the regulatory perimeter, the Central Bank of Ireland has been notably active in attempting to better understand the nature of activities performed by them, and the risks, if any, that they might pose to financial stability. See, for instance, Barrett, Godfrey, and Golden (2016).
} 
of official and privately disclosed data — although partial data suggest that credit intermediation by the industry is still very modest (less than 1 percent of bank loans). Partly on this basis, a recent FSB assessment concluded that there was no evidence to suggest that FinTech presents a compelling financial stability risk in its present forms, which can be broadly distinguished as representing platforms for NBCI or financial innovations that facilitate the growth of shadow banking (FSB 2017c).

However, despite the small size of the sector and the fact that NBCI forms only a part of FinTech activities, particular elements of the rapid growth in FinTech in both advanced and emerging economies point to the need to step up monitoring efforts as the industry expands. These include, for instance, where payments service companies invest the float of customer debit accounts in credit products without the proper expertise, disclosure, or safeguards; where peer-to-peer lending begins to take the form of an originate-to-distribute model without originators being subject to skin-in-the-game requirements; and, at the operational risk level, where poor governance or poor process control could potentially lead to a risk of disruption in the provision of financial services or infrastructure. Over and above direct financial stability issues, a growing FinTech industry will also give rise to important consumer protection and financial integrity concerns (for example, anti-money laundering/combating the financing of terrorism) that authorities will probably need to address. ${ }^{17}$ The broader point is that, as with any financial innovation, it will be incumbent on the relevant agencies to ensure that FinTech serves a public good, like making the financial system more inclusive, without imperiling its health in the process.

\footnotetext{
${ }^{17}$ For a broader recent discussion, see He and others (2017).
} 


\section{Conclusion}

At the November 2010 Seoul Summit, the G20 leaders called for the development of more resilient forms of market-based finance as part of a healthier overall credit mix. Building upon earlier efforts of the FSB, this paper has sought to identify the particular features of NBCI that can make shadow banking a less resilient form of market-based finance. In addition, we identify two broad conclusions that can be drawn from the events that have since unfolded.

First, much progress has been made, most notably in advanced economies, to ensure that many of the types of NBCI activities that amplified the impact of the global financial crisis no longer pose a systemic threat to financial stability. Securitization practices have been strengthened, repo market activities have been overhauled, the MMF industry has been placed on a sturdier footing, and interconnectedness between banks and shadow banks has declined. Reform efforts have aimed at transforming the structural characteristics of riskier aspects of shadow banking, as well as the underlying economic incentives. The business models and resilience of intermediaries have fundamentally changed as a result. These are all welcome developments.

Second, policymakers and market participants should not be lulled into any false comfort that the job is done. In certain areas, like harmonizing retention rules, reforming rating agency practices, and winding back implicit official backstops, there is still more to do. And important data gaps remain with respect to measuring cross-border interconnectedness, potential vulnerabilities associated with collective investment vehicles, and risk concentrations across institutions within specific industries (that is, insurance). A key related priority is to ensure that regulation and supervision are globally coordinated and synchronized, as a defense against the return of cross-border arbitrage. Moreover, policymakers must stay attentive to the emergence of new challenges. The rapid growth of NBCI in EM economies, and new financial 
technologies, stand out in this regard. For all the progress that has been made since the global financial crisis, it remains an open-ended challenge to mitigate the risks while preserving the benefits of all forms of credit growth, thus ensuring that NBCI supports productive risk taking and economic growth well into the future. 


\section{References}

Acharya, Viral A., Philipp Schnabl, and Gustavo Suarez. 2013. "Securitization without Risk Transfer." Journal of Financial Economics 107 (3): 515-36.

Adrian, Tobias. 2015. "Financial Stability Policies for Shadow Banking." In Shadow Banking within and across National Borders, edited by Stijn Claessens, Douglas Evanoff, George Kaufman, and Luc Laeven. World Scientific Studies in International Economics 40. Singapore: World Scientific Publishing Company.

Adrian, Tobias, Nina Boyarchenko, and Or Shachar. 2017. "Dealer Balance Sheets and Bond Liquidity Provision.” Federal Reserve Bank of New York Staff Report 803, New York.

Adrian, Tobias, and Hyun Song Shin. 2009. "The Shadow Banking System: Implications for Financial Regulation." Banque de France Financial Stability Review 13: 1-10.

_. 2011. "Financial Intermediary Balance Sheet Management." Annual Review of Financial Economics 3: 289-307.

Adrian, Tobias, Daniel Covitz, and Nellie Liang. 2013. "Financial Stability Monitoring.” Finance and Economics Discussion Series, Federal Reserve Board, Washington, DC.

Aiyar, Shekhar, Wolfgang Bergthaler, Jose M. Garrido, Anna Ilyina, Andreas Jobst, Kenneth Kang, Dmitriy Kovtun, Yan Liu, Dermot Monaghan, and Marina Moretti. 2015. "A Strategy for Resolving Europe’s Problem Loans." International Monetary Fund Staff Discussion Note 15/19, International Monetary Fund, Washington, DC.

Allen, Franklin, and Douglas Gale. 2000. "Bubbles and Crises." Economic Journal 110 (460): 236-55. 
Allen, Franklin, and Gary Gorton. 1993. "Churning Bubbles.” Review of Economic Studies 60 (4): 813-36.

Ashcraft, Adam B., and Til Schuermann. 2008. "Understanding the Securitization of Subprime Mortgage Credit." Federal Reserve Bank of New York Staff Reports 318, New York.

Baba, Naohiko, Robert N. McCauley, and Srichander Ramaswamy. 2009. "US Dollar Money Market Funds and Non-US Banks." BIS Quarterly Review (March): 65-81.

Bank for International Settlements. 2014. "Re-thinking the Lender of Last Resort.” BIS Paper 79, Basel.

2016. "Revisions to the Securitisation Framework." Basel III Document, July, Basel.

Bank of England and European Central Bank. 2014. "The Case for a Better Functioning Securitisation Market in the European Union.” May, London and Frankfurt.

Barrett, Dominick, Brian Godfrey, and Brian Golden. 2016. "New Data Collection on Special Purpose Vehicles in Ireland: Initial Findings and Measuring Shadow Banking." Central Bank of Ireland Quarterly Bulletin (October).

Claessens, Stijn, Douglas Evanoff, George Kaufman, and Luc Laeven. 2015. Shadow Banking within and across National Borders. World Scientific Studies in International Economics 40. Singapore: World Scientific Publishing Company.

Cole, Harold L., and Thomas F. Cooley. 2014. "Rating Agencies." NBER Working Paper 19972, National Bureau of Economic Research, Cambridge, Massachusetts.

Cornaggia, Jess, and Kimberly Cornaggia. 2013. "Estimating the Costs of Issuer-Paid Credit Ratings." Review of Financial Studies 26 (9): 2229-69.

Coval, Joshua, Jakub Jurek, and Erik Stafford. 2009. "The Economics of Structured Finance.” Journal of Economic Perspectives 23 (1): 3-25.

Dobler, Marc, Simon Gray, Diarmuid Murphy, and Bozena Radzewicz-Bak. 2016. "The Lender of Last Resort Function after the Global Financial Crisis.” IMF Working Paper 16/10, International Monetary Fund, Washington, DC.

European Banking Authority. 2014. "Discussion Paper on Simple Standard and Transparent Securitizations." October, London. 2015. "Report on Qualifying Securitisation.” July. 
Financial Stability Board. 2010. "Principles for Reducing Reliance on CRA Ratings." October, Basel.

— 2016. "Thematic Review on the Implementation of the FSB Policy Framework for Shadow Banking Entities.” May, Basel.

Basel.

. 2017a. "Global Shadow Banking Monitoring Report: 2016.” May,

. 2017b. "Assessment of Shadow Banking Activities, Risks and the Adequacy of Post-Crisis Policy Tools to Address Financial Stability Concerns.” July, Basel.

— . 2017c. "Financial Stability Implications from FinTech: Supervisory and Regulatory Issues that Merit Authorities' Attention.” June, Basel.

_ 2017d. "Policy Recommendations to Address Structural Vulnerabilities from Asset Management Activities.” January, Basel.

—. 2017e. "Implementation and Effects of the G20 Financial Regulatory Reforms: Third Annual Report.” July, Basel.

Gennaioli, Nicola, Andrei Shleifer, and Robert Vishny. 2012. "Neglected Risks, Financial Innovation, and Financial Fragility." Journal of Financial Economics 104 (3): 452-68.

Griffin, John, and Dragon Yongjun Tang. 2012. "Did Subjectivity Play a Role in CDO Credit Ratings?” Journal of Finance 67 (4): 1293-328.

Haldane, Andy. 2014. “The Age of Asset Management?” Speech at the London Business School, London.

He, Dong, Ross Leckow, Vikram Haksar, Tommaso Mancini Griffoli, Nigel Jenkinson, Mikari Kashima, Tanai Khiaonarong, Céline Rochon, and Hervé Tourpe. 2017. "Fintech and Financial Services: Initial Considerations.” IMF Staff Discussion Note 17/05, International Monetary Fund, Washington, DC.

He, Jie, Jun Qian, and Philip Strahan. 2012. "Are All Ratings Created Equal? The Impact of Issuer Size on the Pricing of Mortgage-Backed Securities." Journal of Finance 67 (6): 2097-137.

International Monetary Fund. 2014. "Shadow Banking around the Globe: How Large, and How Risky?” In Global Financial Stability Report: Risk Taking, Liquidity, and Shadow Banking: Curbing Excess while Promoting Growth, Chapter 2. Washington, DC, October.

- 2015. "The Asset Management Industry and Financial Stability." In Global Financial Stability Report: Navigating Monetary Policy Challenges and Managing Risks, Chapter 3. Washington, DC, April. 
International Organization of Securities Commissions (IOSCO). 2015. "Peer Review of Implementation of Incentive Alignment Recommendations for Securitisation: Final Report.” September, Madrid.

Jiang, Xuefeng, Mary Harris Stanford, and Yuan Xie. 2012. "Does It Matter Who Pays for Bond Ratings? Historical Evidence." Journal of Financial Economics 105: 607-21.

Jones, Bradley. 2015. "Asset Bubbles: Rethinking Policy for the Age of Asset Management.” IMF Working Paper 15/27, International Monetary Fund, Washington, DC.

—. 2016. "Spotting Bubbles: A Two-Pillar Framework for Policy Makers." Journal of Banking and Financial Economics 2 (6): 90-112.

Jurek, Jakub W., and Erik Stafford. 2015. "The Cost of Capital for Alternative Investments." Journal of Finance 70 (5): 2185-226.

King, Darryl, Luis Brandao-Marques, Kelly Eckhold, Peter Lindner, and Diarmuid Murphy. 2017. "Central Bank Emergency Support to Securities Markets.” IMF Working Paper 17/152, International Monetary Fund, Washington, DC.

McCulley, Paul. 2007. "Teton Reflections.” PIMCO Global Central Bank Focus. https://www.pimco.com/en-us/insights/economic-and-market -commentary/global-central-bank-focus/teton-reflections

McLoughlin, Kate, and Jessica Meredith. 2017. "The Rise of Chinese Money Market Funds." Reserve Bank of Australia Bulletin (March).

Mishkin, Frederic S. 2010. "Monetary Policy Flexibility, Risk Management, and Financial Disruptions." Journal of Asian Economics 21 (3): 242-46.

_. 2011. "Monetary Policy Strategy: Lessons from the Crisis." NBER Working Paper 16755, National Bureau of Economic Research, Cambridge, Massachusetts.

Muley, Ameya. 2016. "Collateral Reuse in Shadow Banking and Monetary Policy.” Working Paper, Massachusetts Institute of Technology.

Pan, Kevin, and Yao Zeng. 2017. "ETF Arbitrage under Liquidity Mismatch." Working Paper, Harvard University.

Pozsar, Zoltan. 2008. "The Rise and Fall of the Shadow Banking System." Moody's https://www.economy.com/. , Tobias Adrian, Adam Ashcraft, and Hayley Boesk. 2013. "Shadow Banking." Federal Reserve Bank of New York Economic Policy Review 19 (2): 1-16. 
Rajan, Raghuram. 2005. "Has Financial Development Made the World Riskier?” Proceedings - Economic Policy Symposium - Jackson Hole, Federal Reserve Bank of Kansas City, issue Aug, pages 313-69.

Rivlin, Alice M., and John B. Soroushian. 2017. "Credit Rating Agency Reform Is Incomplete.” Brookings Institution, https://www.brookings.edu/ research/credit-rating-agency-reform-is-incomplete/.

S\&P Global Ratings. 2014. "Twenty Years Strong: A Look Back at U.S. CLO Ratings Performance from 1994 through 2013.” January, New York.

Securities and Exchange Commission. 2016. "Annual Report on Nationally Recognized Statistical Rating Organizations.” Washington, DC, December.

Segoviano, Miguel, Bradley Jones, Peter Lindner, and Johannes Blankenheim. 2015. "Securitization: The Road Ahead." IMF Staff Discussion Note 15/01, International Monetary Fund, Washington, DC.

Shleifer, Andrei, and Robert W. Vishny. 1997. "The Limits of Arbitrage." Journal of Finance 52 (1): 35-55.

Singh, Manmohan. 2011. "Velocity of Pledge Collateral: Analysis and Implications." IMF Working Paper 11/256, International Monetary Fund, Washington, DC.

_. 2013. “The Changing Collateral Space.” IMF Working Paper 13/25, International Monetary Fund, Washington, DC.

- 2017. "Collateral Reuse and Balance Sheet Space." IMF Working Paper 17/113, International Monetary Fund, Washington, DC.

Stein, Jeremy C. 2013a. "Overheating in Credit Markets: Origins, Measurement, and Policy Responses." Speech at the Research Symposium "Restoring Household Financial Stability after the Great Recession: Why Household Balance Sheets Matter," Federal Reserve Bank of St. Louis, St. Louis, February 7.

- 2013b. "Lean, Clean and In-Between." Speech at the National Bureau of Economic Research Conference, Lessons from the Financial Crisis for Monetary Policy, Boston, October 18.

Strobl, Gunter, and Han Xia. 2012. "The Issuer-pays Rating Model and Rating Inflation: Evidence from Corporate Credit Ratings." Working Paper, University of Texas, Dallas.

Wurgler, J. 2010. "On the Economic Consequences of Index-Linked Investing.” NBER Working Paper 16376, National Bureau of Economic Research, Cambridge, MA. 
